\title{
Applied welfare economics with discrete choice models: implications of theory for empirical specification
}

\author{
Batley, Richard; Ibáñez Rivas, Juan Nicolás
}

\section{Published in:}

Choice Modelling

Link to article, DOI:

$10.4337 / 9781781007273.00012$

Publication date:

2013

Document Version

Publisher's PDF, also known as Version of record

Link back to DTU Orbit

Citation (APA):

Batley, R., \& Ibáñez Rivas, J. N. (2013). Applied welfare economics with discrete choice models: implications of theory for empirical specification. In S. Hess, \& A. Daly (Eds.), Choice Modelling : The State-of-the-art and the State-of-practice (pp. 144-171). Edward Elgar Publishing. https://doi.org/10.4337/9781781007273.00012

\section{General rights}

Copyright and moral rights for the publications made accessible in the public portal are retained by the authors and/or other copyright owners and it is a condition of accessing publications that users recognise and abide by the legal requirements associated with these rights.

- Users may download and print one copy of any publication from the public portal for the purpose of private study or research.

- You may not further distribute the material or use it for any profit-making activity or commercial gain

- You may freely distribute the URL identifying the publication in the public portal 
EDITED BY

STEPHANE HESS

ANDREW DALY

CHOICE MODELLING The State of the Art and the State of Practice

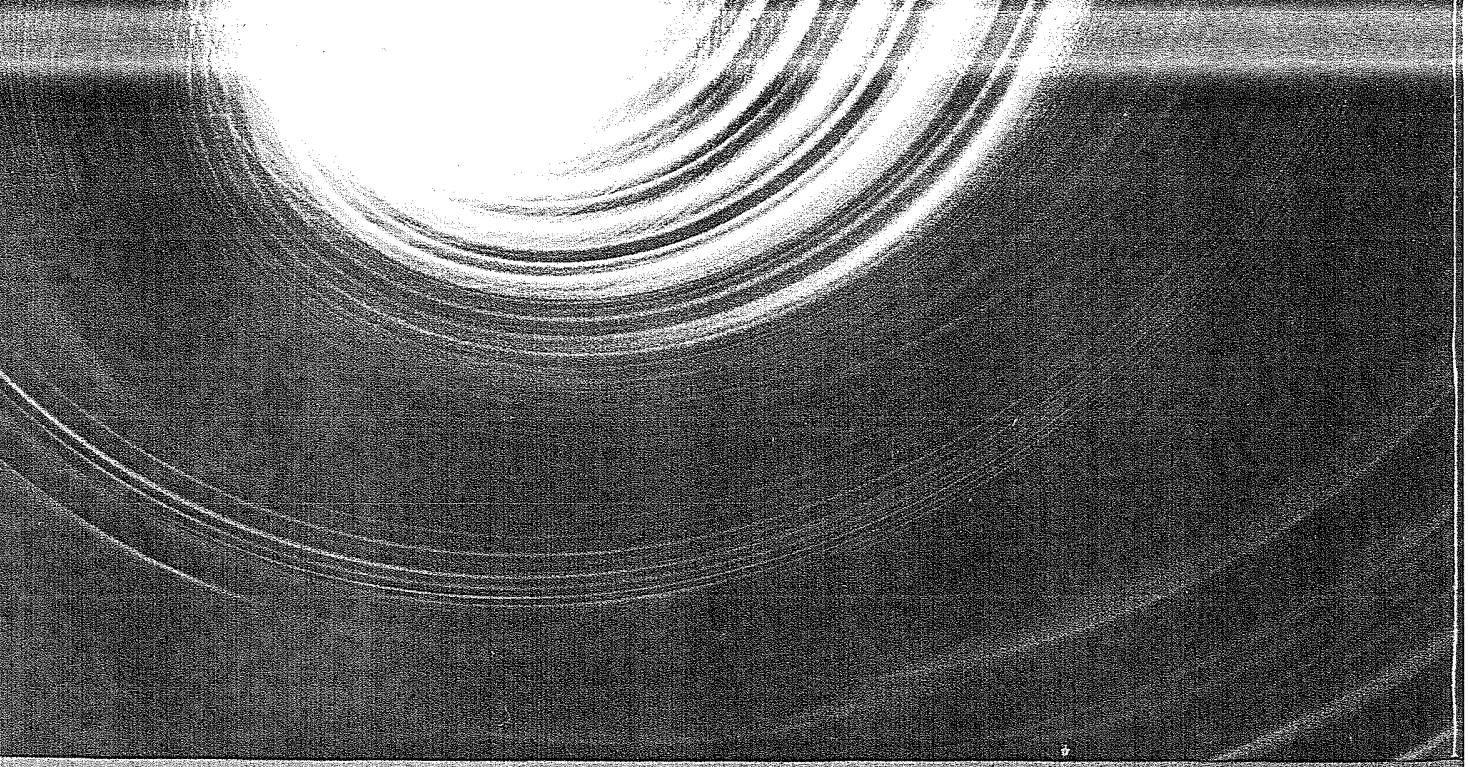




\section{Choice Modelling}

The State of the Art and the State of Practice

Edited by

Stephane Hess

University of Leeds, UK

Andrew Daly

University of Leeds, UK and RAND Europe

Edward Elgar

Cheltenham, UK $\cdot$ Northampton, MA, USA 


\section{Contents}

All rights reserved. No part of this publication may be reproduced, stored in a retrieval system or transmitted in any form or by any means, electronic, mechanical or photocopying, recording, or otherwise without the prior permission of the publisher.

Published by

Edward Elgar Publishing Limited

The Lypiatts

15 Lansdown Road

Cheltenham

Glos GL50 2JA

UK

Edward Elgar Publishing, Inc.

William Pratt House

9 Dewey Court

Northampton

Massachusetts 01060

USA

A catalogue record for this book is available from the British Library

Library of Congress Control Number: 2012955227

This book is available electronically in the ElgarOnline.com Economics Subject Collection, E-ISBN 9781781007273

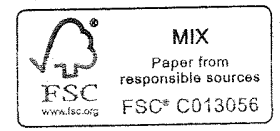

ISBN 9781781007266

Typeset by Servis Filmsetting Ltd, Stockport, Cheshire Printed and bound in Great Britain by T.J. International Ltd, Padstow

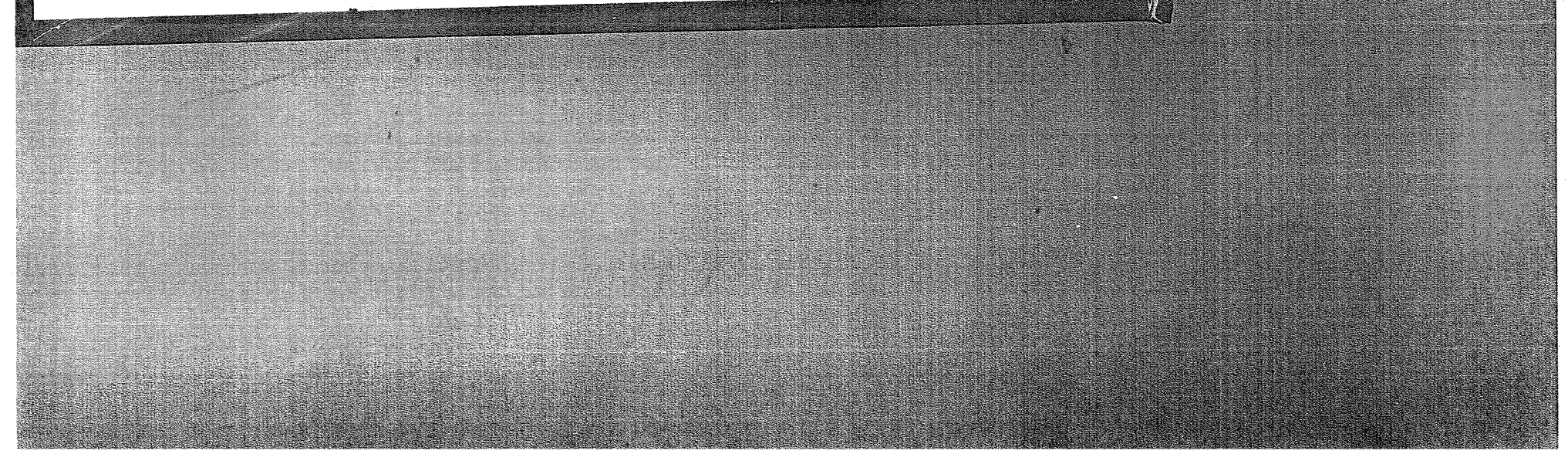




\section{Contents}

reproduced, stored ny means, electronic, vithout the prior

1. Modeling single individuals: the journey from psych lab to the app store

Jordan J. Louviere

2. Forecasting behaviour: with applications to transport Andrew Daly

3. Workshop report: recent advances on modeling multiple discrete-continuous choices

Abdul Pinjari, Chandra Bhat and David S. Bunch

4. Workshop report: working with repeated choice data

Andrew Daly, Stephane Hess and Christine Eckert

5. Workshop report: mental representations and discrete choice behaviour: state-of-the--art and avenues for future research Benedict G.C. Dellaert, Theo Arentze, Caspar G. Chorus, Harmen Oppewal and Geert Wets

6. Workshop report: good data is key to the development of good models so how is innovation in data collection keeping apace?

Rob Sheldon, Martin Dix, Terry Flynn and Paul Metcalfe

7. Applied welfare economics with discrete choice models: implications of theory for empirical specification Richard Batley and J. Nicolás Ibáñez

8. A comprehensive model to capture the preference for mass rapid transit in Dhaka Annesha Enam and Charisma F. Choudhury

9. On the perception of safety in low income neighbourhoods: using digital images in a stated choice experiment Paula Iglesias, Margarita Greene and Juan de Dios Ortuzar

10. How urban environment affects travel behaviour: integrated choice and latent variable model for travel schedules Lissy La Paix, Michel Bierlaire, Elisabetta Cherchi and Andrés Monzón 
11. Selecting a date: a matter of regret and compromises Caspar G. Chorus and John M. Rose

12. Trivariate probit models of pre-purchase/purchase shopping channel choice: clothing purchases in Northern California Patricia L. Mokhtarian and Wei (Laura) Tang

13. Choice models of travel demand in practice: current trends, problems and welcome research directions Peter Vovsha

Index

\section{Contributo}

Theo Arentze Urt Technology, Eindhc Richard Batley Insti

Chandra Bhat Dep Engineering, The U:

Michel Bierlaire $T_{1}$ École Polytechniqus

David S. Bunch Grac Davis

Elisabetta Cherchi I

Caspar G. Chorus S Technology, Delft

Charisma $\mathbb{F}$. Chot Technology

Andrew Daly Insti RAND Europe

Benedict G.C. De Economics, Erasmı Martin Dix MVA ( Christine Eckert $\mathrm{A}$ Choice (CenSoC), '

Annesha Enam Ban

Terry Flymn Centre Technology, Sydne

Margarita Greene: de Chile

Stephane Hess Inst 


\section{Contributors}

current trends,

Theo Arentze Urban Planning Group, Eindhoven University of Technology, Eindhoven

Richard Batley Institute for Transport Studies, University of Leeds

Chandra Bhat Department of Civil, Architectural and Environmental Engineering, The University of Texas at Austin

Michel Bierlaire Transport and Mobility Laboratory (TRANSP-OR), École Polytechnique Fédérale de Lausanne (EPFL)

David S. Bunch Graduate School of Management, University of California, Davis

Elisabetta Cherchi DTU Transport, Technical University of Denmark

Caspar G. Chorus Section of Transport and Logistics, Delft University of Technology, Delft

Charisma F. Choudhury Bangladesh University of Engineering and Technology

Andrew Daly Institute for Transport Studies, University of Leeds and RAND Europe

Benedict G.C. Dellaert Marketing Section, Department of Business Economics, Erasmus School of Economics, Erasmus University Rotterdam

Martin Dix MVA Consultancy

Christine Eckert Marketing Department and Centre for the Study of Choice (CenSoC), The University of Technology, Sydney

Annesha Enam Bangladesh University of Engineering and Technology

Terry Flynn Centre for the Study of Choice (CenSoC), The University of Technology, Sydney

Margarita Greene School of Architecture, Pontificia Universidad Católica de Chile

Stephane Hess Institute for Transport Studies, University of Leeds 
J. Nicolás Ibáñez DTU Transport, Danish Technical University

Paula Iglesias Department of Transport Engineering and Logistics, Pontificia Universidad Católica de Chile

Lissy La Paix Department of Civil Engineering, University of Twente

Jordan J. Louviere Centre for the Study of Choice (CenSoC), The University of Technology, Sydney

Paul Metcalfe PJM Economics

Patricia L. Mokhtarian Department of Civil and Environmental Engineering and Institute of Transportation Studies, University of California, Davis

Andrés Monzón Transport Research Centre TRANSyT, Universidad Politécnica de Madrid

Harmen Oppewal Department of Marketing, Faculty of Business and Economics, Monash University, Melbourne

Juan de Dios Ortúzar Department of Transport Engineering and Logistics, Pontificia Universidad Católica de Chile

Abdul Pinjari Department of Civil and Environmental Engineering, University of South Florida

John M. Rose Institute of Transport and Logistics Studies, The University of Sydney

\section{Rob Sheldon Accent}

Wei (Laura) Tang Transportation Technology and Policy Graduate Program, Institute of Transportation Studies, University of California, Davis

Peter Vovsha Parsons Brinckerhoff

Geert Wets Transportation Research Institute, Hasselt University 


\section{Applied welfare economics with discrete choice models: implications of theory for empirical specification}

\section{Richard Batley and J. Nicolás Ibáñez}

\section{INTRODUCTION}

The apparatus of the Random Utility Model (RUM) first emerged in the early 1960s, with Marschak (1960) and Block and Marschak (1960) translating models originally developed for discriminant analysis in psychophysics (Thurstone, 1927) to the alternative domain of discrete choice analysis in economics. Whilst some researchers were quick to see its practical potential (e.g. McFadden, 1968, 1975), it was not until the late 1970 s and early 1980 s that RUM was equipped with a reasonably comprehensive theoretical rationale in terms of the economics of consumption. An important tenet of this rationale was the link between discrete choice and welfare, which established a basis for applying RUM to public policy analysis, and paved the way for the plethora of applications which have been witnessed over the last 30 years.

It will be helpful to clarify precisely what we mean by 'discrete choice', since Small and Rosen (1981) - which will be referred to as 'S\&R' in the remainder of this chapter - suggest three alternative rationales, as follows. First, commodities may be available in continuous quantities but only a limited number of varieties. Second, goods may be supplied in discrete units of such magnitude that only a small number of those units are typically consumed (in this case, $S \& R$ cite the example of travel mode choice). Third, if the search for the optimal consumption bundle entails a choice between alternative corner solutions, then the problem is reduced to discrete units. S\&R draw particular motivation from the first rationale, introducing a general model of demand comprising both continuous and discrete components. That is to say, an individual is represented as choosing a quantity of a continuous commodity conditional upon discrete choice.

Whilst not overlooking the significant contributions of McFadden
(1981) and Williams (1) influential in establishins can be applied to welfar [their] paper is to demons welfare economics can bi choices are involved' (S\&] 'Throughout, the emphas ing out empirical work' with which RUM has be has stood the test of time; unchallenged and contin policy interventions.

That said, in the years literature (e.g. Hau, 198: 1990; Karlström, 1999; properties of the consume In particular, these contri admits income effects of $k$ will seek to contribute to 1 standing of S\&R, especic provide ". . rigorous guid cifically, our chapter will

1. Section 2 will intr demand, before arti function, and exposi

2. Section 3 will consi the discrete and $\mathrm{cr}$ individual-level and chapter will present ning S\&R's derivati

3. Sections 4 and 5 wi demand with four namely 'adding up'. a restricted case of demand, the chapte specification, sucht

4. Finally, section $6 \mathrm{w}$ ing consumer surpl that the 'log sum' m requirements on $\mathrm{mc}$ the fundamental pr 
(1981) and Williams (1977), S\&R's analysis has proved particularly influential in establishing a basis upon which discrete choice models can be applied to welfare economics. S\&R state that 'The purpose of [their] paper is to demonstrate that the conventional methods of applied welfare economics can be generalised to handle cases in which discrete choices are involved' (S\&R, 1981, p. 106). Furthermore, they remark that: 'Throughout, the emphasis is on providing rigorous guidelines for carrying out empirical work' (p. 106). It is notable that, despite the intensity with which RUM has been applied over the last 30 years, S\&R's paper has stood the test of time; the key propositions of the paper remain largely unchallenged and continue to underpin the analysis of significant public policy interventions.

That said, in the years following its publication, a small but significant literature (e.g. Hau, 1985, 1987; Jara-Díaz and Farah, 1988; Jara-Díaz, 1990; Karlström, 1999; Karlström and Morey, 2004) has clarified the properties of the consumer surplus measure emanating from S\&R's paper. In particular, these contributors have considered the extent to which S\&R admits income effects of both price and income changes. The present paper will seek to contribute to the aforementioned literature by furthering understanding of $S \& R$, especially in a manner that appeals to the aspiration to provide '. . rigorous guidelines for carrying out empirical work'. More specifically, our chapter will offer four substantive contributions, as follows:

1. Section 2 will introduce S\&R's problem of discrete-continuous demand, before articulating the concept of a probabilistic demand function, and exposing the assumptions underlying this concept.

2. Section 3 will consider the application of the Slutsky equation to the discrete and continuous components of demand, from both individual-level and aggregate perspectives. In this regard, the present chapter will present a definitive account of the assumptions underpinning S\&R's derivation of the Slutsky equation.

3. Sections 4 and 5 will reconcile $S \& R$ 's model of discrete-continuous demand with four fundamental properties of demand functions, namely 'adding up', 'negativity', 'homogeneity' and 'symmetry'. For a restricted case of S\&R's model involving only the probabilistic demand, the chapter will identify particular requirements on model specification, such that the aforementioned properties hold.

4. Finally, section 6 will review the rationale followed by S\&R in deriving consumer surplus from discrete choice models. It will be shown that the 'log sum' measure of consumer surplus implies very particular requirements on model specification, consistent with those supporting the fundamental properties of demand functions. 
$\mathrm{m}$ orderings and stochastic theoonomic Information, Decision and $\because$ D. Reidel. multiple choice models', in D.A. of Travel Choice, Farnborough:

inomics and Consumer Behavior, is of time', The Economic Journal, zost-benefit analysis with discrete ).

to cost-benefit analysis in discrete ation corridor simulation model', 357.

1 (2007), 'Flexible substitution patce: new evidence from the UK and $=238$.

ence and the utility function',

Itegrability of demand functions', er and H.F. Sonnenschein (eds), Harcourt Brace

probabilistic choice systems with er, Institute for Transport Studies,

ty relations for discrete-continuous lity', Working paper, Institute for

d the value of travel time savings', 7.

on of users' benefits in transport

and Measurement of Environmental Press.

3radley, M. and F. Hofman (2003), ze using error components logit', 268.

1 modelling and welfare analysis', of Infrastructure and Planning,

lculating the exact compensating with income effects: theory, intuier presented at the meeting of the ins. January 2001.

ses of a government bureaucracy', California, Berkeley, California,

ces of a government bureaucracy: fanagement Science, 6 (2), 401-416.
McFadden, D. (1981), 'Econometric models of probabilistic choice', in C. Manski and D. McFadden (eds), Structural Analysis of Discrete Data: With Econometric Applications, Cambridge, Massachusetts: The MIT Press.

Marschak, J. (1960), 'Binary choice constraints and random utility indicators', in J. Marschak (1974), Economic Information, Decision and Prediction: Selected Essays, vol. 1, Dordrecht: D. Reidel.

Samuelson, P. (1942), 'Constancy of the marginal utility of income', in O. Lange, F. McIntyre and T.O. Yntema (eds), Studies in Mathematical Economics and Econometrics in Memory of Henry Schultz, Chicago: University of Chicago Press.

Samuelson, P. (1950), 'The problem of integrability in utility theory', Economica, 17 (68), 355-385.

Slutsky, E.E. (1915), 'Sulla teoria del bilancio del consumatore', Giornale degli Economisti, 51, 1-26, reprinted as 'On the theory of the budget of the consumer', in J. Stigler and K.E. Boulding (eds), A.E.A. Readings in Price Theory, Chicago: Richard D. Irwin Inc.

Small, K.A. and H.S. Rosen (1981), 'Applied welfare economics with discrete choice models', Econometrica, 49 (1), 105-130.

Steenburgh, T.J. (2008), 'The invariant proportion of substitution property (IPS) of discrete-choice models', Marketing Science, 27 (2), 300-307.

Swait, J. and M. Ben-Akiva (1987), 'Empirical test of a constrained choice discrete model: mode choice in Sao Paulo, Brazil', Transportation Research Part B, 21 (2), 103-115.

Thurstone, L. (1927), 'A law of comparative judgement', Psychological Review, 34, 273-286.

Williams, H.C.W.L. (1977), 'On the formation of travel demand models and economic evaluation measures of user benefit', Environment and Planning A, 9 (3), 285-344. 